\title{
Aplikasi Layanan Administrasi Mahasiswa Jurusan dalam Membangun Tata Kelola Perguruan Tinggi (Studi Kasus: Jurusan Manajemen Informatika Politeknik Negeri Sriwijaya)
}

\author{
Indra Griha Tofik Isa, Indri Ariyanti \\ Jurusan MANAJEMEN INFORMATIKA, Politeknik Negeri Sriwijaya \\ Jl. Srijaya Negara, Bukit Lama, Bukit Besar, Kota Palembang, Sumatera Selatan 30139 \\ "Email: indra_isa_mi@ polsri.ac.id
}

\begin{abstract}
Abstrak
Layanan menjadi faktor utama dalam mengukur kualitas tata kelola di perguruan tinggi, saat ini layanan selalu terintegrasi dengan sistem informasi. Politeknik Negeri Sriwijaya (Polsri) saat ini sudah mengimplementasikan layanan berbasis sistem informasi, namun yang menjadi tantangan dalam pengembangan sistem di Polsri yaitu bagaimana mengakomodir kebutuhan sistem informasi hingga menyasar di level Jurusan dan Program Studi, layanan tersebut bersifat rutin, administratif dan berkaitan langsung dengan mahasiswa. Jurusan Manajemen Informatika (MI) merupakan salah satu jurusan yang memiliki jumlah mahasiswa yang banyak sehingga diperlukan penerapan sistem informasi dalam layanan administrasi mahasiswa. Saat ini sistem layanan yang berjalan di MI masih terpusat pada sistem informasi akademik yang cakupannya meliputi pengeloaan jadwal, penilaian mahasiswa, dan administrasi pengajaran dosen. Namun untuk layanan administrasi mahasiswa belum mengimplementasikan sistem yang terkomputerisasi. Berdasarkan observasi lapangan dan wawancara dengan pengadministrasi jurusan, layanan administrasi yang memerlukan implementasi sistem informasi antara lain: (1) layanan informasi akumulasi kompensasi mahasiswa, (2) layanan pendataan beasiswa, (3) layanan permohonan pelaksanaan Kerja Praktek/ Laporan Akhir/ Tugas Akhir, (4) layanan permohonan Stop Out dan (5) Umpan balik kualitas layanan dari mahasiswa. Hasil akhir dari penelitian ini berupa aplikasi layanan administrasi mahasiswa berbasis web yang mengakomodir layanan mahasiswa dari kelima aspek tersebut
\end{abstract}

\section{Kata kunci: Layanan Administrasi Mahasiswa, Aplikasi berbasis Web, Tata Kelola Sistem} Informasi, SDLC

\section{PENDAHULUAN}

Layanan selalu diintegrasikan dengan sistem informasi, merupakan bagian penting bagi pengelolaan layanan Perguruan Tinggi. Layanan berbasis sistem informasi memberikan gambaran bagaimana tata kelola di sebuah institusi berjalan dengan baik (Asriyanik \& Indra, 2018). Saat ini aspek pelayanan institusi memiliki tantangan tersendiri, terlebih bila dikaitkan dengan budaya mutu suatu organisasi. Berbagai macam inovasi melalui pendekatan sistem terkomputerisasi dikembangkan guna memenuhi kualitas dari layanan sehingga sesuai dengan standar mutu yang sudah ditetapkan. Terlebih dengan adanya era revolusi industri 4.0, Perguruan Tinggi dituntut harus memiliki inovasi digital maupun adaptasi dengan teknologi tersebut. Perubahan paradigma konvensional terutama dalam aspek layanan, saat ini sudah beralih ke dalam digitalisasi guna mendukung tata kelola Perguruan Tinggi yang memiliki kecepatan akses data (real time), kehandalan, dan menjadi penunjang dalam rekomendasi pengambilan keputusan.

Politeknik Negeri Sriwijaya (Polsri) merupakan salah satu Perguruan Tinggi Negeri yang berada di Palembang terus menerus berupaya untuk meningkatkan kualitas layanannya. Saat ini Polsri sudah menerapkan layanan yang terintegrasi dengan sistem informasi, diantaranya layanan akademik melalui Sistem Informasi Akademik Polsri (sisak.polsri.ac.id), layanan penelitian dan pengabdian masyarakat melalui sim.p3m.polsri.ac.id, layanan kemahasiswaan melalui kemahasiswaan.polsri.ac.id serta beberapa layanan lainnya yang bersifat terpusat (Pusat Informasi dan Humas, 2020). Hal yang menjadi tantangan dalam pengembangan sistem di Polsri yaitu bagaimana mengakomodir kebutuhan sistem informasi hingga menyasar di level Jurusan dan Program Studi, layanan tersebut bersifat rutin, administratif dan berkaitan langsung dengan mahasiswa. 
Jurusan Manajemen Informatika (MI) merupakan salah satu jurusan yang memiliki peminat yang tinggi, berdasarkan data yang diperoleh dari Forlap Dikti tercatat bahwa pada tahun akademik 2020/2021 semester ganjil, jumlah mahasiswa aktif MI sebanyak 1053 mahasiswa yang terdiri dari program studi D-III MI sebanyak 550 mahasiswa dan D-IV MI sebanyak 503 mahasiswa. Dari banyaknya mahasiswa tersebut, maka diperlukan dukungan dengan penerapan teknologi informasi dan inovasi, sehingga layanan mahasiswa dapat dilaksanakan secara optimal. Saat ini Jurusan MI dalam pengelolaan sistem informasi masih terpusat sebatas sisak.polsri.ac.id yang cakupannya meliputi pengolahan jadwal, penilaian mahasiswa, dan administrasi pengajaran dosen. Dari segi layanan administrasi mahasiswa, jurusan MI belum memiliki pengelolaan layanan yang terkomputerisasi. Hal ini dapat dilihat dalam pemberian informasi akumulasi kompensasi mahasiswa masih dilakukan dengan cara menghubungi pengadministrasi jurusan secara langsung. Hal ini tentunya akan menjadi kendala ketika pengadministrasi jurusan tidak sedang berada di tempat untuk menginformasikan berapa akumulasi kompensasi, serta perlunya jeda waktu untuk membuka data akumulasi kompensasi mahasiswa. Kendala lainnya yang masih ditemukan yaitu belum adanya sistem informasi proses pendataan beasiswa yang menyebabkan data pendukung yang dilampirkan oleh mahasiswa seperti Surat Keterangan Tidak Mampu (SKTM), Kartu Hasil Studi (KHS) dan Rekening Listrik tidak diarsipkan secara digital sehingga jurusan berpotensi kehilangan rekam jejak mahasiswa penerima beasiswa. Permasalahan yang terakhir yaitu dalam pembuatan Surat Permohonan Izin pelaksanaan Kerja Praktek / Laporan Akhir / Tugas Akhir bagi instansi dan perusahaan serta Surat Pengajuan Stop Out (SO), selama ini mahasiswa meminta langsung ke pengadministrasi jurusan yang dilakukan secara berkerumun. Hal ini tentunya tidak efektif dikarenakan dapat terjadi penumpukan antrian di Jurusan, mengingat situasi pandemi COVID19 saat ini yang mengharuskan untuk mematuhi protokol kesehatan dengan tidak berkerumun pada suatu tempat.
Dari beberapa hal yang terjadi di atas diperlukan solusi cermat dan inovatif yang memberikan kepastian data dan informasi bagi mahasiswa selaku stakeholder penerima layanan. Tidak hanya kepastian data dan informasi, namun juga layanan administrasi mahasiswa jurusan dapat terukur kualitasnya melalui penilaian yang dilakukan oleh mahasiswa berupa survey kepuasan layanan atau umpan balik, hasil dari penilaian tersebut dapat memberikan rekomendasi masukan bagi jurusan mengenai hal-hal yang harus ditingkatkan dan dipertahankan.

Berdasarkan uraian latar belakang tersebut, permasalahan yang diangkat dalam penelitian ini meliputi

1. Belum adanya sistem terkomputerisasi yang menangani layanan pada tingkat jurusan, seperti: layanan informasi akumulasi kompensasi mahasiswa, layanan pengajuan beasiswa, layanan pengajuan surat permohonan izin Kerja Praktek / Laporan Akhir / Tugas Akhir bagi instansi / perusahaan dan Surat Permohonan Stop Out (SO)

2. Potensi ketidakpastian data dan informasi yang diterima oleh mahasiswa sebagai stakeholder penerima data, yang menyebabkan penurunan kualitas dari layanan jurusan

3. Tidak adanya sistem yang mengukur kualitas layanan di jurusan yang dilakukan secara objektif dan transparan.

Sehingga Rumusan Masalah dari penelitian ini sebagai berikut:

"Bagaimana mengimplementasikan inovasi layanan administrasi mahasiswa secara terkomputerisasi sehingga meningkatkan mutu dan kualitas layanan di Jurusan Manajemen Informatika Politeknik Negeri Sriwijaya saat ini?"

Aspek layanan yang diakomodir dalam sistem meliputi: (1) layanan informasi akumulasi kompensasi mahasiswa, (2) layanan pengajuan beasiswa, (3) layanan pengajuan surat permohonan izin Kerja Praktek / Laporan Akhir / Tugas Akhir bagi instansi / perusahaan, (4) Layanan Surat Permohonan Stop Out (SO) serta (5) survey kepuasan layanan jurusan oleh mahasiswa.

Perancangan sistem secara terstruktur dengan pemodelan diagram konteks, Data Flow Diagram (DFD), Entity Relationship Diagram 
(ERD). Sedangkan Tools dan bahasa pemrograman menggunakan HTML, CSS, JavaScript untuk Front End Programming dan PHP serta basis data MySQL untuk Back End Programming

Pengujian dilakukan melalui pendekatan

Black Box Testing dengan membuat skenario pengujian yang melibatkan mahasiswa, pengadministrasi jurusan dan pimpinan jurusan.

\section{TINJAUAN PUSTAKA}

\subsection{Tata Kelola Teknologi Informasi}

Teknologi informasi (TI) saat ini sudah menjadi kebutuhan yang sangat penting bagi hampir semua organisasi perusahaan karena dipercaya dapat membantu meningkatkan efektifitas dan efisiensi proses bisnis perusahaan, tak terkecuali perguruan tinggi. Kesuksesan tata kelola perusahaan (enterprise governance) saat ini mempunyai ketergantungan terhadap sejauh mana tata kelola TI (IT Governance) dilakukan (Utomo \& Mariana, 2011).

Tata kelola teknologi informasi adalah salah satu bagian terpenting dari kesuksesan penerapan good corporate governance (GCG). Tata kelola teknologi informasi (IT Governance) memadukan best practices proses perencanaan, pengelolaan, penerapan, dan pelaksanaan, serta pengawasan kinerja untuk memastikan bahwa dengan adanya teknologi informasi benar mendukung pencapaian tujuan perusahaan (Wibowo et al., 2021)

\subsection{Budaya Mutu Perguruan Tinggi}

Budaya mutu merupakan sistem nilai yang dimiliki suatu organisasi dan sistem tersebut menghasilkan lingkungan yang bersifat kondusif untuk keberlangsungan dan keberlanjutan perbaikan mutu (Mulyadi, 2010). Budaya mutu menjadi dasar dalam menciptakan kondisi layanan akademik yang baik dan memuaskan, setiap perguruan tinggi harus menerapkan sistem manajemen layanan yang bermutu melalui berbagai rangkaian kegiatan yang tersusun dalam rencana induk pengembangan layanan perguruan tinggi. Selain itu, pengertian lain budaya mutu adalah sistem nilai organisasi yang menciptakan lingkungan yang kondusif untuk keberlangsungan perbaikan mutu yang berkesinambungan.

Budaya mutu merupakan bagian yang tidak terpisahkan dari sebuah prosedur, tradisi, nilai-nilai dan harapan tentang promosi mutu. Sedangkan tujuan dari budaya mutu adalah untuk membentuk suatu lingkungan organisasi yang memiliki sistem nilai, tradisi, dan aturanaturan yang mendukung untuk mencapai perbaikan mutu secara terus menerus (Madiarsa, 2017)

\subsection{Sistem Informasi}

Sistem merupakan gabungan dari kegiatan atau prosedur yang saling terkait, yang melaksanakan dan mempermudah kegiatan ataupun proses bisnis utama dari suatu organisasi. Sedangkan informasi merupakan hasil dari pengolahan atau pemrosesan data, yang mana memiliki nilai kebermaknaan bagi si penerima informasi tersebut. Informasi memiliki usia/ batas waktu, yang berarti sampai kapan informasi memiliki arti/nilai kebermanfaatan bagi si penerima informasi itu sendiri (Kadir, 2014). Adanya acuan pada titik waktu tertentu dan pernyataan suatu perubahan pada suatu waktu. Kualitas Informasi tergantung dari 3 hal (Rosa \& Shalahuddin, 2018), yaitu informasi harus :

1. Akurat, yang berarti bahwa informasi tersebut bebas dari kesalahan maupun informasi yang dapat menyesatkan. Misalnya hoax yang mana tingkat kebenarannya tidak valid. Akurat bahwa berarti informasi harus jelas mencerminkan apa maksud dan tujuannya

2. Tepat pada waktunya, yang berarti informasi sesuai dengan timing yang dibutuhkan oleh si penerima informasi

3. Relevan, yang berarti informasi tersebut mempunyai nilai kebermaknaan bagi si penerima informasi. Relevansi informasi untuk tiap-tiap orang satu dengan yang lainnya berbeda.

Dari penjelasan tersebut dapat disimpulkan bahwa sistem informasi merupakan sekumpulan elemen atau subsistem yang saling terkait secara komputerisasi, yaitu mengolah data menjadi informasi bagi pihak yang berkepentingan sehingga mencapai visi dari suatu organsiasi tertentu.

\subsection{Layanan Jurusan Manajemen Informatika}

Layanan Jurusan MI terintegrasi dalam standar operasional prosedur (SOP) jurusan, terdapat 38 SOP yang terdiri dari SOP bidang tridharma (pengajaran, penelitian dan 
pengabdian masyarakat) dan non-tridharma (Badan Penjaminan Mutu, 2017). Di dalam layanan tersebut mengakomodir kebutuhan dosen (bidang tridharma) maupun mahasiswa dari aspek layanan pengajaran. Selain struktural program studi maupun jurusan, pengadministrasi jurusan memiliki peran sentral dalam bagaimana memaksimalkan layanan tersebut demi mencapai mutu layanan. Adapun tugas pokok dan fungsi (tupoksi) pengadministrasi jurusan sebagai berikut:

1. Membuat surat menyurat dan mengarsipkan surat yang masuk dan keluar

2. Membuat, memperbanyak dan merekap absensi dosen, administrasi dan mahasiswa

3. Melayani kebutuhan alat-alat praktek, alat tulis mahasiswa dan dosen

4. Melaksanakan evaluasi program studi dari bagian akademik

5. Menyiapkan surat menyurat yang berhubungan dengan kegiatan jurusan

6. Menyiapkan segala sesuatu yang berkaitan dengan magang

7. Melaksanakan persiapan evaluasi (ujian)

8. Mengumpulkan nilai dari dosen untuk dibuatkan transkrip

9. Menyiapkan keperluan untuk wisuda dan mahasiswa baru

10.Melaksanakan tugas lain yang diberikan oleh atasan

\subsection{Penelitian Terdahulu}

Beberapa penelitian terdahulu yang terkait dengan layanan antara lain yang telah dilakukan oleh (Ahmed et al., 2017) yaitu dihasilkan aplikasi layanan mahasiswa terkait pendaftaran akun internet perguruan tinggi. Perancangan sistem secara berorientasi objek dengan pemodelan Unified Modelling Language yang terdiri dari Use Case diagram, Class Diagram, Sequence Diagram, dan Activity Diagram. Penelitian lainnya menghasilkan produk aplikasi administrasi akademik Jurusan Teknik Elektronika berbasis Android yang bertujuan untuk meningkatkan aspek layanan administrasi jurusan dan memberikan kepuasan terhadap mahasiswa di perguruan tinggi khususnya jurusan Teknik Elektronika Fakultas Teknik Universitas Negeri Padang. Aplikasi dirancang juga berbasis client-server. Tahapan perancangan pada aplikasi ini, yaitu analisis kebutuhan sistem, desain sistem, pembuatan kode dan pengujian.
Metode yang digunakan pada perancangan yaitu metode waterfall yang terdiri dari analisis kebutuhan, perancangan, implementasi dan pengujian. Perancangan antar muka terdiri dari halaman home, halaman login, halaman input pelayanan, halaman update dan delete pelayanan dan halaman pelayanan yang diterima (Effendi \& Tasrif, 2019)

Sementara (Sunoto, 2015) membangun sistem informasi akademik berbasis web dengan ruang lingkup administrasi surat menyurat yang didalamnya dilakukan perekaman surat masuk dan surat keluar. Perancangan sistem menggunakan perancangan terstruktur dengan pemodelan diagram konteks, Data Flow Diagram, Entity Relationship Diagram. Sedangkan implementasi sistem menggunakan bahasa pemrograman berbasis web.

Penelitian lainnya yang dilakukan oleh (Melani, 2019) berfokus pada layanan administrasi mahasiswa di tingkat lembaga, antara lain BAAK, Keuangan dan Sarana Prasarana. Penelitian ini dilatarbelakangi oleh Pemanfaatan TIK terutama penerapan penggunaan sistem informasi pada bidang layanan administrasi akademik di perguruan tinggi saat ini menjadi suatu kebutuhan wajib supaya dapat meningkatkan daya saing perguruan tinggi.

Adapun yang menjadi keterbaruan dalam penelitian ini lebih menitikberatkan pada aspek layanan administrasi mahasiswa di jurusan Manajemen Informatika, yang terdiri dari (1) Layanan informasi akumulasi kompensasi mahasiswa; (2) Layanan pengajuan beasiswa, (3) Layanan pengajuan surat permohonan izin Kerja Praktek / Laporan Akhir / Tugas Akhir bagi instansi / perusahaan dan (4) Surat Permohonan Stop Out (SO). Namun sebagai alat ukur dalam melihat kualitas layanan jurusan, diintegrasikan dengan (5) Survey kepuasan layanan jurusan oleh mahasiswa. Penelitian yang diusulkan ini menggunakan bahasa pemrograman berbasis web dan perancangan terstruktur, yang diharapkan memiliki nilai usability bagi penggunanya, baik pengadministrasi jurusan, mahasiswa maupun pimpinan jurusan (Kajur / Sekjur / Kaprodi). 


\section{METODE PENELITIAN}

Metode penelitian dalam perancangan Aplikasi Layanan Administrasi Mahasiswa dapat dilihat pada gambar 1 berikut ini:

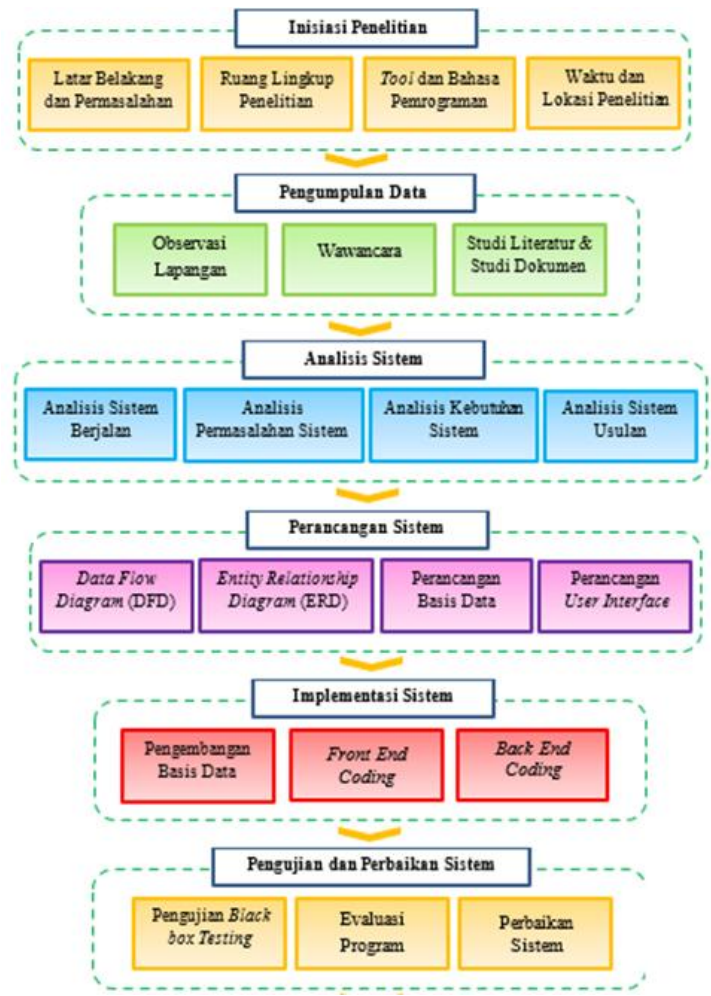

Gambar 1. Metode Penelitian

Metode penelitian dilakukan dengan pendekatan Research \& Development dengan hasil akhir berupa luaran produk Rancang Bangun Sistem Layanan Administrasi Mahasiswa Jurusan (Studi Kasus: Jurusan Manajemen Informatika Politeknik Negeri Sriwijaya). Berikut ini penjabaran tahapan penelitian pada gambar 1 .

\subsection{Inisiasi Penelitian}

Merupakan tahapan awal dalam pelaksanaan penelitian. Dalam inisiasi penelitian dilakukan perumusan permasalahan yang melatarbelakangi dari penelitian yang akan dilakukan, aspek batasan / ruang lingkup penelitian, tools dan bahasa pemrograman yang akan diimplementasikan ke dalam sistem serta tempat dan durasi penelitian.

\subsection{Pengumpulan Data}

Pengumpulan data dilakukan dengan 3 teknik, yakni Observasi, Wawancara dan Studi Literatur. Dalam proses wawancara melibatkan beberapa pihak yang ada di Jurusan Manajemen Informatika, antara lain: (1) Pimpinan Jurusan (Kajur / Sekjur / Kaprodi D-IV); (2) Bagian Pengadministrasi Jurusan; (3) Perwakilan dari Himpunan Mahasiswa Jurusan (HMJ); dan (4) Beberapa perwakilan mahasiswa di tingkat 1,2, 3 dan 4 Program Studi D-III dan D-IV Manajemen Informatika. Sebelum dilakukan proses wawancara, terlebih dahulu dibuat skenario wawancara terkait aspek layanan yang disesuaikan dengan kapasitas narasumber. Adapun konsep skenario wawancara yang akan diberikan kepada narasumber ditunjukan oleh tabel 1:

Tabel 1. Konsep Skenario Wawancara Narasumber

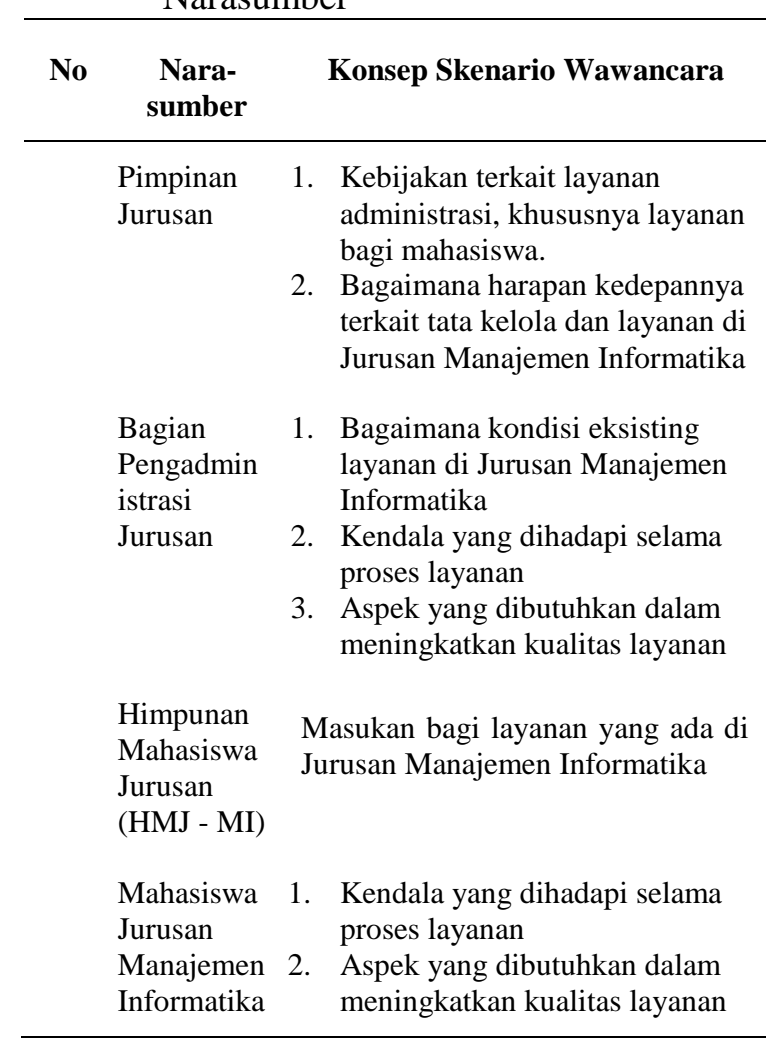

Selanjutnya tahapan observasi dilakukan dengan cara mengamati langsung pelayanan administrasi mahasiswa yang ada di Jurusan Manajemen Informatika. Dengan melihat bagaimana pengadministrasi layanan melakukan proses layanan kepada mahasiswa

Sedangkan dalam studi pustaka dengan mereferensikan penelitian-penelitian terdahulu 
terkait rancang bangun sistem layanan administrasi

\subsection{Analisis Sistem}

Dokumen yang dihasilkan pada tahapan pengumpulan data selanjutnya dianalisis, baik dalam analisis sistem berjalan, analisis permasalahan, analisis kebutuhan maupun analisis sistem usulan. Dalam analisis sistem berjalan direpresentasikan dengan flowchart / flowmap / workflow diagram. Dari diagram tersebut dapat dilihat bagaimana alur data, baik dari segi input, proses maupun output dari sistem yang belum dilakukan secara terkomputerisasi. Temuan-temuan maupun potensi kerentanan yang muncul dalam analisis sistem berjalan selanjutnya dianalisis ke dalam analisis permasalahan, secara teknis permasalahan tersebut diuraikan dan diberikan solusi dengan pendekatan teknologi informasi.

Solusi yang dihasilkan dalam analisis permasalahan selanjutnya dilakukan penjabaran lebih lanjut kedalam spesifikasi kebutuhan sistem yang disebut dengan analisis kebutuhan sistem. Terdapat 2 aspek yang dianalisis, yakni analisis spesifikasi kebutuhan perangkat lunak dan analisis spesifikasi kebutuhan perangkat keras. Berikutnya yaitu analisis sistem usulan, dalam analisis ini sistem yang diusulkan dirancang ke dalam bentuk flowchart / flowmap / blockchart / workflow diagram..

\subsection{Perancangan Sistem}

Hasil dari analisis pada tahapan sebelumnya menjadi dasar dalam perancangan sistem. Secara teknis dalam perancangan sistem dilakukan secara terstruktur dengan pembuatan: (1) Diagram Konteks, (2) Data Flow Diagram (DFD), (3) Entity Relationship Diagram (ERD), (4) Perancangan Basis Data dan Normalisasi Tabel, (5) Hierarchy Input Process Output (HIPO), (6) Kamus Data, (7) Rancangan Tampilan Antarmuka Pengguna dan Pseudocode.

\subsection{Implementasi Sistem}

Tahapan implementasi sistem merupakan proses coding dari perancangan yang sudah dilakukan dalam tahapan perancangan sistem. Implementasi sistem membangun sistem berbasis web dengan menggunakan beberapa bahasa pemrograman, untuk frontend yakni HTML, CSS, JavaScript. Sedangkan untuk backend menggunakan bahasa pemrograman PHP dan basis data MySQL. Framework yang digunakan dalam implementasi sistem yaitu Bootstrap, framework sistem ini memiliki User Interface (UI) yang dapat diandalkan.

\subsection{Pengujian dan Perbaikan Sistem}

Pengujian dilakukan terhadap rancang bangun layanan administrasi mahasiswa jurusan untuk menguji keandalan dan keefektifan dari sistem tersebut. Pendekatan yang dilakukan dalam pengujian sistem dilakukan dengan Metode Pengujian Blackbox Testing menguji dari aspek fungsional sistem. Dalam pengujian ini melibatkan beberapa pihak yang terkait langsung sebagai entitas dari sistem, antara lain pimpinan jurusan, pengadministrasi jurusan dan mahasiswa. Dalam proses pengujian Blackbox Testing, entitas tersebut diberikan matriks skenario pengujian sistem, seperti pada gambar 2.

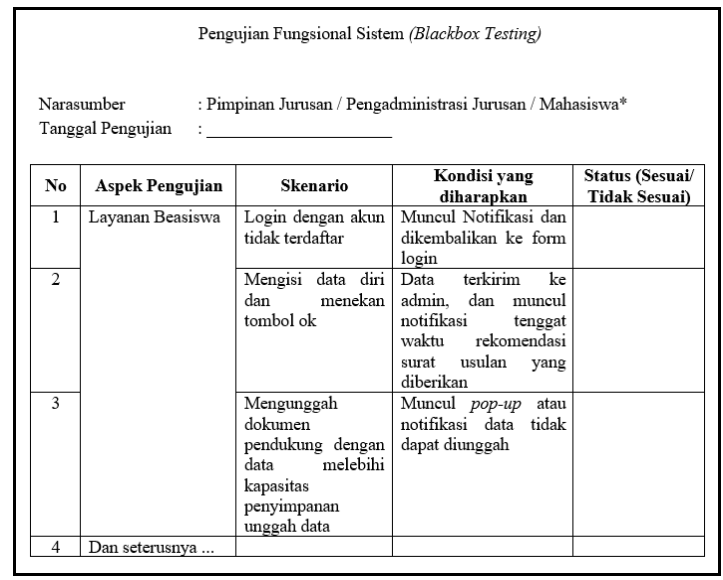

Gambar 2. Skenario Blackbox Testing

Berdasarkan hasil Blackbox Testing jika muncul temuan ketidaksesuaian secara fungsional, maka akan dilakukan evaluasi sistem atau perbaikan minor sehingga rancang bangun sistem layanan administrasi dapat diimplementasikan di Jurusan Manajemen Informatika sesuai dengan kebutuhan dan memenuhi dari aspek usability pengguna. Dalam tahapan ini menghasilkan Luaran : Dokumen hasil Blackbox Testing. 


\section{HASIL DAN PEMBAHASAN}

Perancangan sistem dilakukan secara terstruktur dengan merancang diagram konteks, Data Flow Diagram, Entity Relational Diagrami, Perancangan Basis Data, Tampilan antar muka pengguna. Berikut diagram perancangan yang dibuat dalam sistem yang dibangun:

\subsection{Diagram Konteks}

Berikut diagram konteks dari perancangan sistem yang dibangun seperti ditunjukan oleh gambar 3.

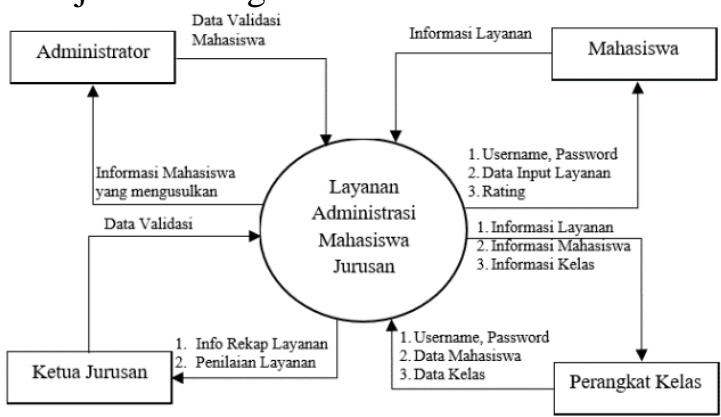

Gambar 3. Diagram Konteks

Diagram konteks diatas menunjukkan 4 entitas yang berinteraksi langsung dengan sistem yang terdiri dari Administrator, Mahasiswa, Ketua Jurusan dan Perangkat Kelas. Dari masing-masing entitas tersebut dapat dilihat alur data secara umum dari/ke entitas ke sistem ataupun sebaliknya.

\subsection{Data Flow Diagram}

Dari diagram konteks yang dirancang di atas selanjutnya diterjemahkan ke dalam proses yang lebih rinci dalam Data Flow Diagram (DFD) terdapat 7 proses utama dalam DFD yakni login, input data user, input data kompen, informasi kompen mahasiswa, pengajuan beasiswa, pengajuan surat administrasi dan penilaian layanan administrasi. Gambar 4. menunjukkan DFD level 1

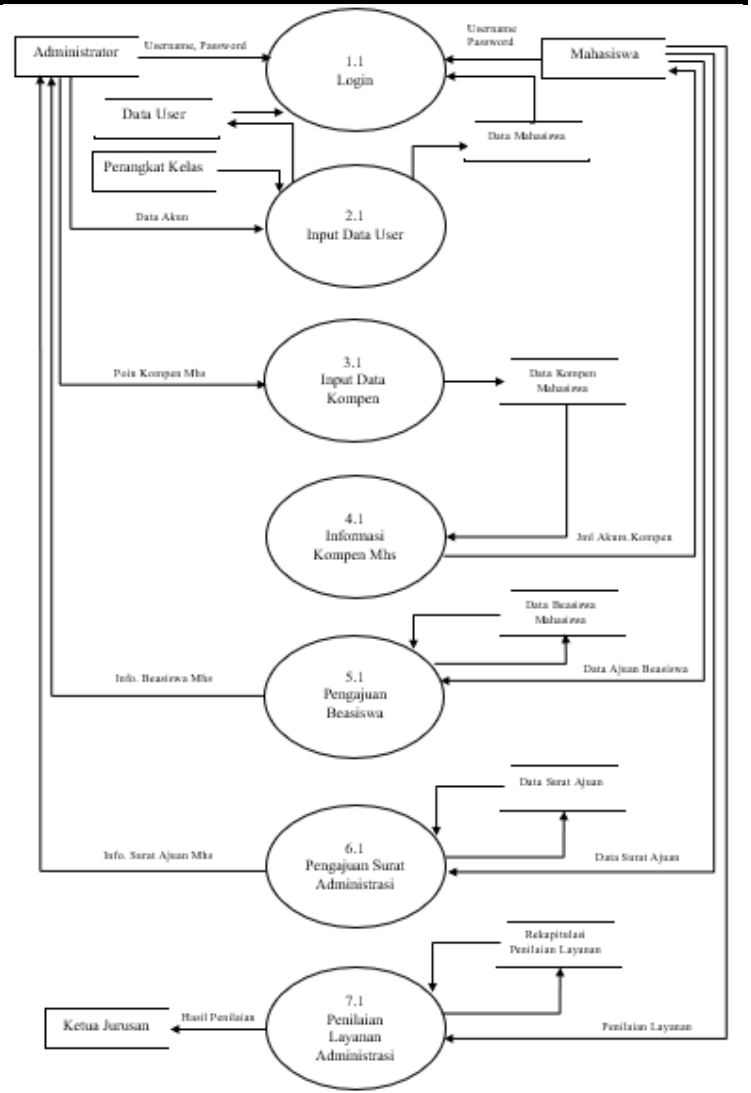

Gambar 4. DFD Level 1

Dari DFD Level 1 di atas di-breakdown proses pengajuan surat administrasi kedalam DFD Level 2 yang terdiri dari Surat Permohonan KP/LA/TA, Surat Permohonan Stop Out dan Cetak Surat seperti yang terdapat dalam gambar 5

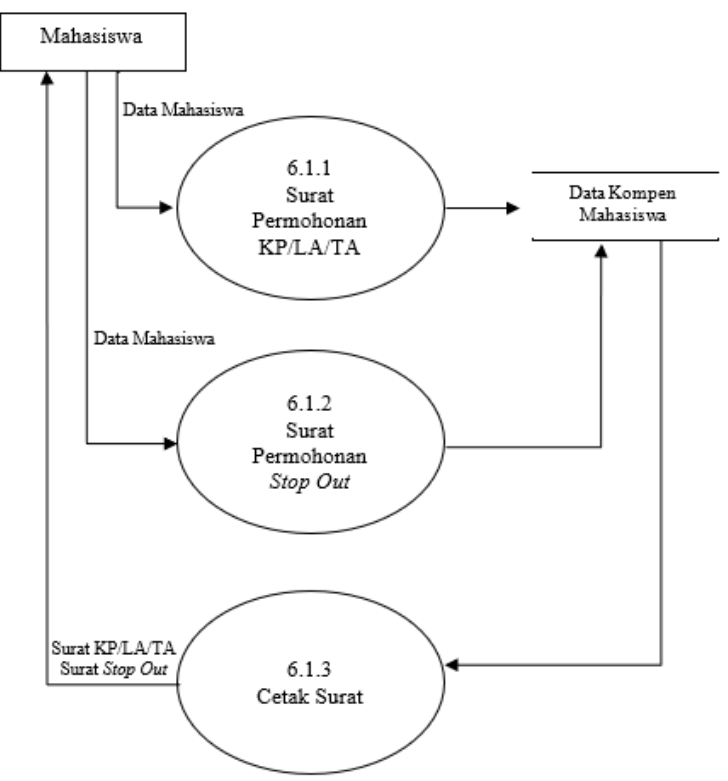

Gambar 5. DFD Level 2 


\subsection{Entity Relational Diagram}

Untuk merelasikan data model dari masing-masing entitas maka dirancang Entity relationship diagram (ERD) seperti pada gambar 6.

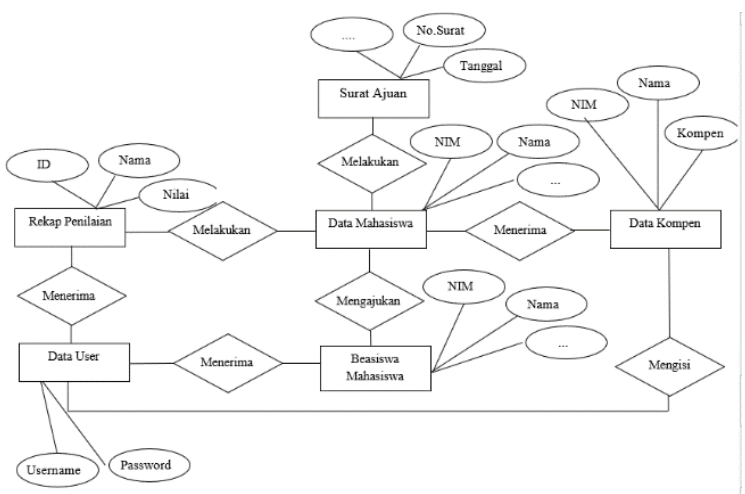

Gambar 6. ERD Aplikasi Layanan Administrasi Mahasiswa

\subsection{Perancangan Basis Data}

Berikut merupakan tabel dari rancangan basis data layanan administrasi mahasiswa jurusan, dengan nama basis data dblayananmahasiswa yang terdiri dari 6 tabel yakni tbdataMahasiswa, tbRekapNilai, tbDataUser, tbSuratAjuan, TbBeasiswaMhs, tbDataKompen seperti yang ditunjukkan oleh tabel 2 hingga tabel 3 .

Tabel 2. Tabel Data Mahasiswa

\begin{tabular}{lccc}
\hline \multicolumn{1}{c}{ Field } & Tipe Data & Length & Ket \\
\hline NIM & Int & 15 & Primary \\
NamaMhs & Varchar & 30 & \\
Semester & Int & 2 & \\
Kelas & Varchar & 7 & \\
Jenis & Boolean & & \\
Kelamin & & & \\
Alamat & Varchar & 35 & \\
\hline
\end{tabular}

Tabel 3. Tabel Rekap Penilaian

\begin{tabular}{lccc}
\hline \multicolumn{1}{c}{ Field } & Tipe Data & Length & Ket \\
\hline ID & Int & 5 & Primary \\
Tanggal & Date & shortdate & \\
Nilai 1 & Int & 4 & \\
Nilai 2 & Int & 4 & \\
Nilai 3 & Int & 4 & \\
Nilai 4 & Int & 4 & \\
\hline
\end{tabular}

Tabel 4. Tabel Data User

\begin{tabular}{lccc}
\hline \multicolumn{1}{c}{ Field } & Tipe Data & Length & Ket \\
\hline ID & Int & 4 & Primary \\
Username & Varchar & 15 & \\
Password & Varchar & 15 & \\
\hline
\end{tabular}

Tabel 5. Tabel Surat Ajuan

\begin{tabular}{lccc}
\hline \multicolumn{1}{c}{ Field } & Tipe Data & Length & Ket \\
\hline ID & Int & 4 & Primary \\
Tanggal & Date & Shortdate & \\
NIM & Int & 15 & \\
NamaMhs & Varchar & 30 & \\
Semester & Int & 2 & \\
TipeAjuan & Int & 20 & \\
\hline
\end{tabular}

Tabel 6. Tabel Beasiswa Mahasiswa

\begin{tabular}{lccc}
\hline \multicolumn{1}{c}{ Field } & Tipe Data & Length & Ket \\
\hline ID & Int & 4 & Primary \\
NIM & Int & 15 & \\
Dokumen1 & Blob & & \\
Dokumen2 & Blob & & \\
Dokumen3 & Blob & & \\
Dokumen4 & Blob & & \\
Tanggal & Date & shortdate & \\
\hline
\end{tabular}

Tabel 7. Tabel Data Kompen

\begin{tabular}{lccc}
\hline \multicolumn{1}{c}{ Field } & Tipe Data & Length & Ket \\
\hline ID & Int & 4 & Primary \\
NIM & Int & 15 & \\
TotalKompen & Int & 5 & \\
Tanggal & Date & shortdate & \\
\hline
\end{tabular}

\subsection{Rancangan Tampilan Antarmuka}

Gambar 7 s.d. 9 merupakan rancangan tampilan antarmuka pengguna dari Aplikasi Layanan Administrasi Mahasiswa Jurusan:

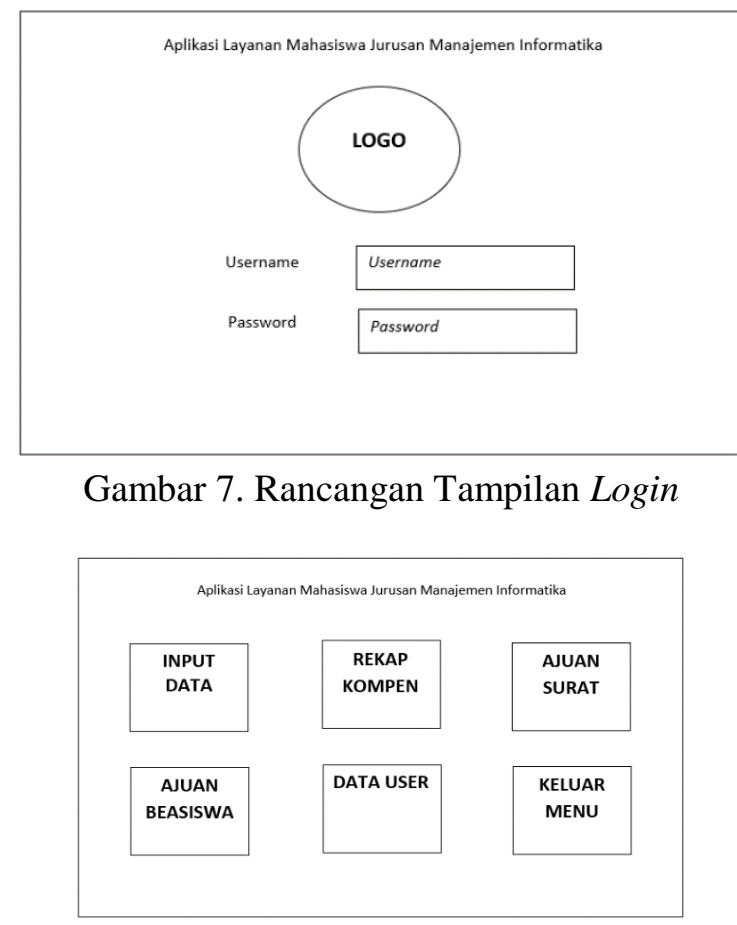

Gambar 8. Rancangan Tampilan Menu Utama 


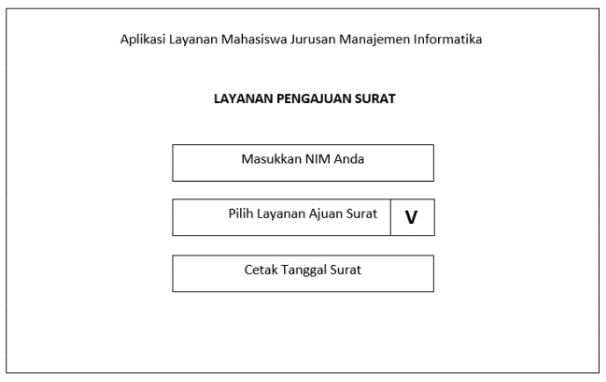

Gambar 9. Rancangan Tampilan Menu Layanan Pengajuan Surat

\subsection{Implementasi Sistem}

Berdasarkan hasil perancangan di atas, selanjunya dilakukan implementasi coding dengan bahasa pemrograman web (HTML, CSS, PHP dan Javascript. Gambar 10 s.d. 12 merupakan tampilan implementasi antarmuka pengguna dari aplikasi yang dibangun

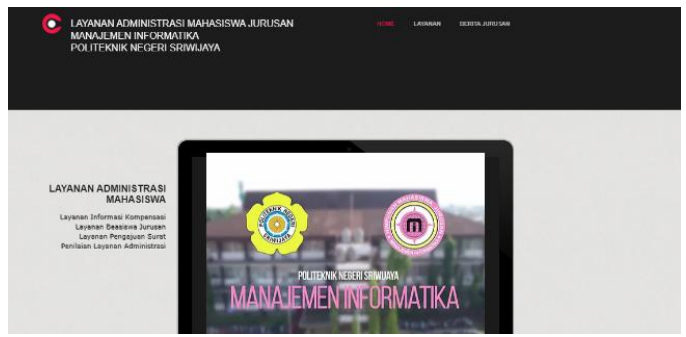

Gambar 10. Screenshot tampilan Dashboard Utama

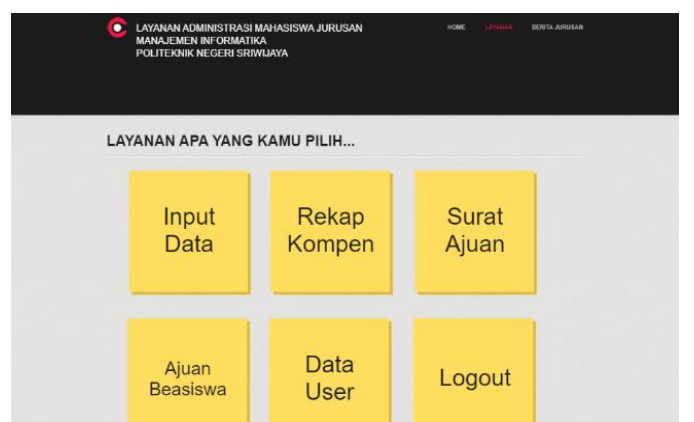

Gambar 11. Screenshot Tampilan Menu Layanan Administrasi Jurusan

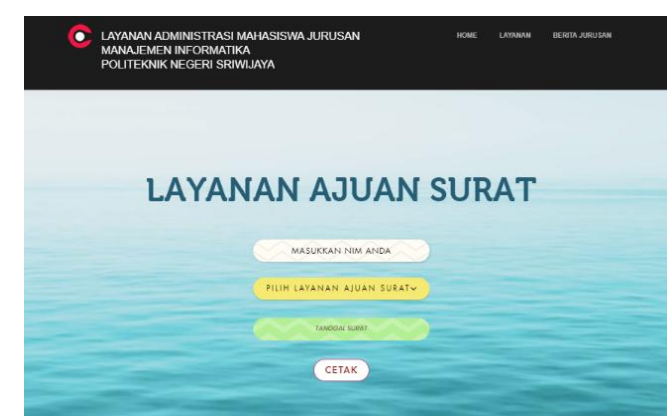

Gambar 12. Screenshot tampilan Menu Ajuan Surat

\subsection{Pengujian Sistem}

Pengujian sistem dilakukan dengan Blackbox Testing dengan menguji aspek fungsionalitas dari sistem. Dalam tahapan pengujian melibatkan beberapa pihak baik user mahasiswa, pengadministrasi jurusan dan pimpinan jurusan yang terdapat 36 butir pengujian yang diberikan ke pihak penguji sistem. Tabel 8. menunjukkan hasil dari Blackbox Testing:

Tabel 8. Hasil Blackbox Testing

\begin{tabular}{|c|c|c|}
\hline Skenario Uji & Hasil Pengujian & Ket \\
\hline $\begin{array}{l}\text { Menginput User } \\
\text { name dan password } \\
\text { dengan data yang } \\
\text { tidak sesuai }\end{array}$ & $\begin{array}{l}\text { Muncul pop-up dan } \\
\text { tidak masuk ke } \\
\text { sistem }\end{array}$ & $\mathrm{OK}$ \\
\hline Mengklik menu & Masuk ke menu & $\mathrm{OK}$ \\
\hline Rekap Kompen & Rekap Kompen & \\
\hline Mengklik menu & Masuk ke menu & $\mathrm{OK}$ \\
\hline Surat Ajuan & Surat Ajuan & \\
\hline Mengklik menu & Masuk ke menu & OK \\
\hline Input Data & Input Data & \\
\hline Mengklik menu & Masuk ke menu & OK \\
\hline Ajuan Beasiswa & Ajuan Beasiswa & \\
\hline Mengklik menu & Masuk ke menu & OK \\
\hline Data User & Data User & \\
\hline Mengklik menu & Muncul pertanyaan & OK \\
\hline Logout & $\begin{array}{l}\text { konfirmasi logout } \\
\text { dan keluar dari } \\
\text { sistem }\end{array}$ & \\
\hline $\begin{array}{l}\text { Mengklik tombol } \\
\text { cetak dalam menu }\end{array}$ & $\begin{array}{l}\text { Muncul print } \\
\text { preview surat yang }\end{array}$ & $\mathrm{OK}$ \\
\hline $\begin{array}{l}\text { Layanan Surat } \\
\text { Ajuan }\end{array}$ & akan dicetak & \\
\hline
\end{tabular}

\section{KESIMPULAN}

Aplikasi layanan administrasi jurusan yang terdiri dari layanan informasi akumulasi kompensasi mahasiswa, layanan pengajuan beasiswa, layanan pengajuan surat permohonan izin Kerja Praktek / Laporan Akhir / Tugas Akhir bagi instansi / perusahaan dan Surat Permohonan Stop Out (SO) memberikan kemudahan bagi mahasiswa dalam proses layanan administrasi jurusan. Aplikasi yang dibangun memberikan kepastian data, khususnya informasi akumulasi kompensasi yang diterima oleh mahasiswa. Aplikasi layanan memberikan rekomendasi kualitas layanan melalui umpan balik yang diberikan oleh user setiap kali user menerima layanan administrasi. Penelitian yang dilakukan dapat dikembangkan lebih lanjut baik dari aspek 
kompleksitas maupun tools teknologi yang diimplementasikan. Dari segi aspek kompleksitas terkait administrasi jurusan, di dalam subsistem rekap kompen dapat diintegrasikan dengan penilaian sikap mahasiswa yang terdapat dalam Sistem Informasi Akademik (SISAK) Polsri. Sedangkan dari segi tools teknologi yang digunakan, dapat dikembangkan dengan mengimplementasi pemrograman berbasis mobile. Sehingga sistem dapat dijalankan dalam perangkat mobile khususnya berbasis Android.

\section{DAFTAR PUSTAKA}

Ahmed, T. H., Kadhar, L. A., \& Shameemfathima, A. (2017). A Design of Mobile Application for University Management Systems Using Android. International Journal of Information Technology (IJIT), 3(2), 6-11. www.ijitjournal.org

Asriyanik, A., \& Isa, I. G. T. (2018). Rancang Bangun Sistem Layanan Administrasi Berbasis Website Pada Fakultas Sains Dan Teknologi Universitas Muhammadiyah Sukabumi (Ummi). Santika: Jurnal Ilmiah Sains dan Teknologi, 8(1), 655-664.

Badan Penjaminan Mutu. (2017). Standar Operasional Prosedur Jurusan. BPM Polsri.

Effendi, S. P., \& Tasrif, E. (2019). Perancangan Digitalisasi Pelayanan Administrasi Akademik Jurusan Teknik Elektronika Berbasis Android. JVOTEKNIKA:Jurnal Vokasional Teknik Elektronika Dan Informatika, 7(2).

Kadir, A. (2014). Pengenalan Sistem Informasi edisi Revisi. Penerbit Andi.

Madiarsa, I. M. (2017). MEMBANGUN PERGURUAN TINGGI BERBUDAYA MUTU. Prosiding Seminar: Revitalisasi Tata Kelola Perguruan Tinggi, 2, 213217.

Melani, Y. I. (2019). Sistem Pengaduan Layanan Akademik Menggunakan Responsive Web Design. Sisfokom, 08(1), 39-45.

Mulyadi. (2010). Kepemimpinan dalam Mengembangkan Budaya Mutu. UINMaliki Press.

Pusat Informasi dan Humas. (2020). CETAK BIRU

PERENCANAAN
PENGEMBANGAN TEKNOLOGI INFORMASI DAN KOMUNIKASI POLITEKNIK NEGERI SRIWIJAYA TAHUN 2020 - 2024. Politeknik Negeri Sriwijaya.

Rosa, A. S., \& Shalahuddin, M. (2018). Rekayasa Perangkat Lunak Terstruktur dan Berorientasi Objek. Penerbit Informatika.

Sunoto, I. (2015). Perancangan Sistem Informasi Administrasi. TEKNIK FTUP Faktor Exacta, 28(1), 146-155. http://publikasi.dinus.ac.id/index.php/join s/article/view/1459

Utomo, A. P., \& Mariana, N. (2011). Analisis Tata Kelola Teknologi Informasi (IT Governance) pada Bidang Akademik dengan Cobit Frame Work Studi Kasus pada Universitas Stikubank Semarang. Jurnal Teknologi Informasi DINAMIK, 16(2), 139-149.

Wibowo, N. S., Utami, E., \& Alfatta, H. (2021). Perancangan Struktur Tata Kelola Data di Pemerintah Daerah Menggunakan Framework Data Management Body Of Knowledge. Journal of Computer, Information System, and Technology Management, 4(1). 